\title{
The Ability of Early Childhood Social Interaction Based on Gadget Giving by Parents in Sukorejo Village, Gunungpati District of Semarang City
}

\author{
Laely Hidayati, Diana \\ Universitas Negeri Semarang, Semarang, Indonesia \\ e-mail: laelyhidayati72@gmail.com
}

\begin{abstract}
Parents generally provide gadgets to their children as a means of education and entertainment. Facts on the ground, there are two kinds of ways parents provide gadgets to children, the first is that parents allow the gadget to run every day, the second parent provides gadgets on certain days. Giving gadget to early childhood also negatively affects the child so that the child becomes undisciplined in the use of learning time, playing time, meal time and rest time. When children play gadgets, children usually forget time and ignore the surrounding environment. As a result, the child becomes anti-social. This parent is very contributory in limiting time and watching when the child is given a gadget. The purpose of this study was to explain the differences between early childhood social interactions based on the provision of gadgets by parents in Sukorejo Village, Gunungpati District of Semarang City. This research is a comparative quantitative research with research subjects are parents who have children aged 5-6 years who provide gadgets to children every day and on certain days in Sukorejo Village, Gunungpati District of Semarang City. The techniques of data collection in this study were using the scale of children's social interaction based on the provision of gadgets by parents, while the data analysis used a different test or independent sample t-test. The results of the study stated that there were no differences in social interaction between early childhoods based on the gadget facility by parents in the Sukorejo Village, Gunungpati District of Semarang City. It was proven by the statistical calculation, the value of the sig- 2 tailed is 0.940 , which means the value of the sig- 2 tailed $>0.05$, it means that the hypothesis test being rejected. The early childhood social interaction based on the everyday and certain day gadgets providing in Sukorejo Village, Gunungpati District of Semarang City had the same score in the high category, which was $46.6 \%$ on everyday given and $46.6 \%$ on a certain day. The suggestions for parents, they have to be more selective in giving toys to the children, and need assertiveness, mentoring from parents so that the gadget does not give a negative impact later that can interfere with the child's growth and development process, especially the development of social interaction.
\end{abstract}

Keywords: Social Interaction Ability, Early Childhood, Gadget

\section{INTRODUCTION}

Technology development in Indonesia is increasing as evidenced by the increasingly diverse types of gadgets with various types that are widespread in the Indonesia. The use of gadgets in early childhood is used for learning tools or media for children. They can open features that can help in the child's learning process, not only used to play games. The use of gadgets among children is increasingly alarming and certainly has a negative impact on growth and development. It is clear that children adapt more quickly to existing technology compared to the surrounding environment, so that the social interaction between children and the surrounding community decreases, even fading.

Dewi et.al (2016) argued that children as gifts from God mandated to be treated, guided and 
educated will become human resources in the future to continue the nation in realizing the nation's ideas. According to Mutiah (2010: 3) that suggested that this age which is commonly called the golden age at this age only came once and could not be repeated, and at this age it was very decisive to develop human quality to the next stage. How important education is for children who need guidance from teachers and of course parents in coloring children's relationships with peers and their social environment. In addition to the stimulus obtained from schools, several factors are also able to influence children's growth and development, including maternal education, maternal work, father's education, father's work and children's environmental factors.

According to Anapratiwi et.al (2013) who argues that humans are essentially social beings who have the urge to interact with the surrounding environment. According to Ayuningtyas (2013), that a process of interaction between parents and children, these interactions include care such as from fulfilling food needs, encouraging success and protecting, as well as socializing that is teaching general behavior accepted by the community. Thus, it is parents who are modeling for their children. Antara (2016) argues that family is the first and foremost environment for children who have a large influence. In line with Rini (2017), that suggests that social development in childhood grew out of child relationships with family members. In addition to these things, the child's curiosity and interest at this age is very high. So parents must be very clever and firm in giving restrictions. A great sense of curiosity and interest for children about something they can get from the five senses, which may be when the child first sees, hears, touches, smells, or feels the child feels interesting, funny, fun, and colorful. Parents need to monitor and pay attention to every stimulus that can affect social development in children.

Various types of parents in educating and supervising their children vary according to what parents want. Giving or allowing children to play gadgets not all parents allow. Facts in the field there are parents who set their children's schedules in playing gadgets on certain days, for example children are only allowed to play gadgets on Saturdays and Sundays, besides that there are also parents who free their children every day playing gadgets. Some parents answered that they gave gadgets to their children so parents quickly finished doing homework and the children were calm with their gadgets.

Naim (2015) argues that social skills are very important for children. This will be an establishment when children enter a wider social world, where the influence of friends and social environment will affect their lives. Mutmainnah (2012) argues that parental care in parenting greatly influences the formation of children's behavior, because from the treatment of this parent the child will get impressions that will shape his social behavior. Putri (2013) argues that individuals as social beings are required to have good social adjustment skills. Therefore social adjustment skills should be taught early. If the child's home is less interacting with family members, it is likely to occur outside the child's home, it is difficult to interact with their peers.

According to Ahmadi (2009: 49) social interaction is a relationship between an individual and an individual or an individual with a group, where individuals change each other, influence each other, from another individual the individual can change, learn and vice versa. One skill that must be owned by children is the ability of social interaction. If social interaction since early childhood is good, the next stage of interaction will be better too. Pangaribuan (2017) argues that the first individual socialization and social interaction process is family. Apriyanti (2016) argues that social interaction ability is part of important social development to be carried out early on.

Waygood, et.al (2017: 23) explained that social interaction helps children feel the sensuality of the community as well as for welfare in the life of the next child. This journal describes how parents feel safe when social interaction is built early, because when children travel alone or go to school on their own using a bicycle and something happens on the trip the child immediately asks or requests for help with people around the trip without shame or fear. On the contrary, lack of social interaction with people other than family allows children to experience lower levels of well-being when they leave because public relations can affect the sense of security for children and their parents.

The use of gadgets also has a significant negative impact on children. With the ease of accessing various information and technology media, it is caused children to become lazy to move and move. They prefer to sit quietly in front of the gadget and enjoy the world inside the gadget. They 
have gradually forgotten the pleasure of playing with friends their age or family members. It certainly will have a negative impact on the health and development of children. In addition, spending too much time in front of the gadget screen makes children's social interactions also suffer. (Mesman, et al. 2013: 456) suggests that many children now depend on the technology behind it and that they depend on technology, the technology affected by communication in families that is hampered and the daily activities of the family become difficult. The hope of this research is that parents keep watching and limiting the time when giving gadgets to their children. In addition, the researcher hopes that parents should pay more attention or be wise in giving gadgets to their children. Parents should have more time with their children so that the family becomes a place for the means to interact and the child's social interaction ability can develop according to his age.

According to preliminary observations on January 8, 2018 at TK Pertiwi 44 Sukorejo, Gunungpati, it was found that there were two children from TK A who brought their mobile phones to school. The child brought a cellphone to open a game, a video of a children's song. The following day observations obtained additional data that according to parents said almost all children were familiar with gadgets since the age of three or four years. When a cellphone is placed in a place that is easily known to the child and the parent is careless, the child will take it. The duration of gadget usage varies, from 30 minutes to more than 3 hours a day. In general, children will cry and get angry when their phones are taken by their parents. Since getting to know gadgets, children are more difficult to be reminded and ignorant when invited to talk. If it continues to be left unchecked, it will have a negative impact on children's social development. The giving of stimulus in stimulating children's social development is not easy. Many factors influence both from the outside and from within the child.

Based on the facts that occur in the field, researcher is interested in researching the topic of the ability of early childhood social interaction based on the provision of gadgets by parents. The advantage of this study is that the variable of giving a gadget is divided into two classes, namely the class of giving gadgets every day and the class of giving gadgets for certain days. Compared to previous studies, previous researchers only saw an influence between gadget usages on early childhood social interaction, while this study aimed to explain differences in early childhood social interactions based on the provision of gadgets by parents in Sukorejo Village, Gunungpati District of Semarang City.

\section{METHOD}

The method of this study is quantitative research approach with comparative methods. The dependent variable (y) in this study is the social interaction of children aged 5-6 years. The independent variable $(x)$ in this study is the provision of gadgets by parents. The population in this study were all parents of TK B students in the 2017/2018 school year in kindergartens in Sukorejo Village, Gunungpati District of Semarang City, as many as 210 parents of kindergarten students B. Researcher took samples from parents of kindergarten students B from TK Pertiwi 44 and TK An-Nur who giving gadgets to their children, with a total sample of 30 student parents, which were 14 guardians of TK Pertiwi 44 students and 16 guardians of TK An-Nur students. The number of parents who give gadgets to children every day 15 parents and 15 other parents provide gadgets to their children on certain days.

This research was conducted at Pertiwi 44 and An-Nur Kindergarten located in Sukorejo Village, Gunungpati District of Semarang City, Central Java. This research was conducted on May 30, 2018 to June 6, 2018. Data collection instruments used questionnaires made by writer to see the scale of children's social interaction. This questionnaire was intended for parents of each child. The procedure for processing the results of research data is carried out through the normality and homogeneity test. After the data is proven to be normal and homogeneous, then data analysis is performed using independent sample t-test.

\section{RESULT AND DISCUSSION}

The research was conducted at Pertiwi 44 and An-Nur Kindergarten located in Sukorejo village, Gunungpati District, Semarang City. Sukorejo village is a village in Gunungpati Subdistrict, Semarang City with an area of 288,063 ha. It is divided by 70 RT and 12 RW. Geographical location of Sukorejo village is between Sekaran and Sadeng village. The calculation results can be seen from the 
calculation of descriptive data. In the descriptive calculation the provision of gadgets every day and certain days has the same early childhood social interaction in the high category.

In determining the high and low social interaction of early childhood based on the provision of gadgets every day and certain days by parents in Sukorejo village, Gunungpati Subdistrict, Semarang City, the categorization of the scale of early childhood social interactions was made into three parts, namely high, medium, and low based on the normal curve distribution using standard deviation formula.

Table 1. The Result of Data Collecting of Early Childhood Social Interaction based on Gadget Providing by Parents

\begin{tabular}{|c|c|c|c|c|c|c|c|}
\hline \multirow{3}{*}{$\begin{array}{l}\text { Class } \\
\text { Interva } \\
\text { I }\end{array}$} & \multirow[t]{3}{*}{$\begin{array}{l}\text { Categor } \\
\mathbf{y}\end{array}$} & \multicolumn{2}{|c|}{$\begin{array}{l}\text { Giving } \\
\text { parents }\end{array}$} & \multicolumn{2}{|c|}{ a gadget by } & \multicolumn{2}{|c|}{ Total } \\
\hline & & \multicolumn{2}{|c|}{ Every day } & \multicolumn{2}{|c|}{$\begin{array}{l}\text { Certain } \\
\text { day }\end{array}$} & \multirow[b]{2}{*}{$\mathbf{N}$} & \multirow[b]{2}{*}{$\%$} \\
\hline & & $\mathbf{N}$ & $\%$ & $\mathbf{N}$ & $\%$ & & \\
\hline $66 \leq x$ & High & 14 & $\begin{array}{l}46,6 \\
\%\end{array}$ & 14 & $\begin{array}{l}46,6 \\
\%\end{array}$ & 28 & $93,3 \%$ \\
\hline $\begin{array}{l}44 \leq X \\
<66\end{array}$ & Medium & 1 & $3,4 \%$ & 1 & $3,4 \%$ & 2 & $6,67 \%$ \\
\hline$X<66$ & Low & - & - & - & - & - & - \\
\hline Total & & 15 & $50 \%$ & 15 & $50 \%$ & 30 & $100 \%$ \\
\hline
\end{tabular}

Based on the data above, it can be seen that most children have a high category of social interaction, namely 28 children $(93.3 \%)$ in the medium category, namely 2 children $(6.67 \%)$. The category table above shows a table of general social interaction ability categories. If the views on the terms of granting gadget every day and certain days that are comparable, both in the high category as much as $46.6 \%$ and comparable categories pad also low at $3.4 \%$. So, in this study found that the absence of differences in early childhood social interactions was based on giving gadgets by parents. The results of this study are supported by his research Radliya et.al (2017) which entitled the effect of device usage on early social emotional development of children, namely social emotional development has developed well by $87 \%$ and the results of his research indicate that emotional social development influenced by devices only $8.2 \%$ in the very category low.

Based on the table 2, it can be seen that the results of the t-test calculation using the SPSS application obtained a sig (2-tailed) value 0.940 . This means the value of sig (2-tailed) $>0.05$ and $t$ value also $>0.05$. Thus $\mathrm{Ho}$ is accepted and $\mathrm{Ha}$ is rejected, the results are obtained "There is no difference in social interaction of early childhood based on the provision of gadgets by parents in Sukorejo Village, Gunungpati District, Semarang City". This proves that the provision of gadgets every day and certain days by parents does not have a significant difference even though children have a longer time than playing gadgets on giving certain day gadgets compared to giving gadgets every day by parents.

Every parent would want his child to be a person of good personality, a healthy mental attitude and good character. Parents are the first personal formers in children's lives, and must be good examples for their children. According to Ambaryanti in Saputri (2017: 11) that every child is a gift for parents in the world, the first education for children is the family as a character, personality, and attitude maker of children before they get formal education. Parents have full responsibility for their children's life. Early childhood education is a preparing effort that is shown to children from birth up to six years of age, which is carried out through the provision of educational stimuli to help growth and physical and spiritual development. In educating children, there are various forms of parenting that can be chosen and used by parents. Before

Table 2. The Result of Independent Sample T-test

Independent Samples Tes




proceeding to the next discussion, the understanding of parenting itself will first be presented.

It is undeniable that the development of digital technology has a special impact on early childhood. The daily behavior of parents, especially in the use of gadgets, often involves their children. The nature of children who tend to want to know and try to imitate what parents do requires the participation of parents so that children can be wise in using gadgets.

Based on the research that has been done, the giving of gadgets every day and certain days by parents in Sukorejo Village, Gunungpati District of Semarang City shows that half of the respondents or 15 respondents answered every day they or their parents allowed, let, and provided gadgets to their children, half the other respondents or 15 respondents answered that parents gave, allowed and let their children to play gadgets on certain days.

Apriyanti (2016) explained that if social interaction developed early, children will be able to work together, share, appreciate, and help others. As stated in the following quote "Social interaction ability is a part of the social development which is important to develop early, with good social interaction abilities, children will be able to cooperate, share, respect and help other people." Generally when children are 4 years old they can maintain friendships that are raised. When a child is dealing with a friend, the child will show an attitude that is often bigger, easier to cooperate, more positive and more pointing to disagreement. The acknowledgments of social development, children can adjust themselves to groups of peers and the surrounding community. The social skills that children have are in line with their psychosocial stages.

When entering the preschool age children will enter a wider social world compared to previous ages. Children usually have begun to enter educational institutions that allow them to interact with people outside the family structure, such as the teachers and peers. According to research by Mauladin (2013) that explained the way children build knowledge at the age of 5-6 years is through social interaction. Through social interaction the child can learn something from others, namely when the child examines or sees objects when told by other parties.

The number of respondents in this study is 30 parents with characteristics that have children aged 5-6 years. In general, parents who have children aged 5-6 years have been included in early childhood education institutions. Based on the research that has been done, the percentage of the answers to statement items can be seen in the attachment of social interaction of 5-6 year olds in Sukorejo Village, Gunungpati Subdistrict of Semarang City, showing the majority of parents or respondents answered agreeing on the item statement that reads "Children are able to carry out orders according to what was ordered", 20 parents or $67 \%$ of respondents answered agreed to the item statement. Another data of $57 \%$ of parents answered if their children were able to be invited to collaborate with their family or friends. Of the two items, the majority of children's interactions with respondents have developed well.

As many as $60 \%$ of respondents said they agreed that if their children wanted to be friends with anyone, it meant that the tolerance of the children had begun to develop by not selecting the other peers. And $57 \%$ of respondents answered strongly agree that children are able to show empathy. From the answers to these items, the child has developed according to his age. The majority of the social interaction abilities of children aged 5-6 years in Sukorejo Village have developed according to their age.

\section{CONCLUSION}

Based on the discussion of the results of the study, it showed that early childhood social interaction was based on the provision of gadgets that every day and certain days in Sukorejo Village, Gunungpati District of Semarang City had a high social interaction of children, which was $46.6 \%$ on a daily basis and $46.6 \%$ on certain days. Based on statistical calculations, obtained the tail-tailed value 0,940 which means the value of the sig- 2 tailed > 0.05 with the results of the hypothesis test being rejected. The results of this study stated that there were no differences in social interaction between early childhoods based on the provision of gadgets by parents in the Sukorejo village, Gunungpati District of Semarang City. The suggestions for parents are they should be more selective in giving toys to children, and need assertiveness, mentoring from parents so that later the gadget does not give a negative impact that can interfere with the child's growth and development process, especially the development of social interaction. 


\section{REFERENCES}

[1] Ahmadi, A. (2009). Psikologi Sosial. Jakarta : Rineka Cipta.

[2] Anapratiwi, D. (2013). Hubungan Antara Kelekatan Anak Pada Ibu Dengan Kemampuan Sosialisai Anak Usia 4-5 Tahun (Studi Pada RA Sinar Pelangi dan RA Al Iman Kecamatan Gunungpati. Indonesian Journal Of Early Childhood Education Studies (IJECES) 2(2).

[3] Antara, P, A. (2016). Reconstruct the Aggressiveness Therapy of Child (Case Study on Ratna Kumara Kindergarten, Medahan Village, Blahbatuh, Gianyar, Bali. Journal Of Early Childhood Education Studies (IJECES) 5(1).

[4] Apriyanti, K., \& Diana, D. (2016). The implementation of Project Based Learning Models in Improving Social Interaction Ability on Children Aged 5-6 Years in Dharma Wanita Bumimulyo Kindergarten Batangan District Pati Regency. Early Chidhood Education Papers (BELIA), 5(2), 88-92.

[5] Ayuningtyas, D. (2013). Orientasi Pola Pengasuhan Anak Usia Dini Pada Keluarga Militer Di Asrama Kodam Kelurahan Jatingaleh Cnadisari Semarang. Journal Of Early Childhood Education Studies (IJECES) 2(2).

[6] Dewi, K \& Handayani, D. (2016). Parenting Parent The Twins in Tambakromo Pati. Early Chidhood Education Papers (BELIA), 24-29.

[7] Mauladin, D. (2013). The Effects of Learning Methods and Environmental Knowledge on Age 5-6 Naturalistic Intelligence (Experiment at AR-Ridho Nature Kindergaten Group B Tembalang Semarang). Asia Pacific Journal of Multidisciplinary Research, 1(1).

[8] Mesman, dkk. (2013). The Impact of Technology Dependence on Children and Their Families. Journal of Pediatric Health Care Volume 27 Number 6.

[9] Mutiah, D. (2010). Psikologi Bermain Anak Usia Dini. Jakarta : Prenada Media Grup.
[10] Mutmainah, S. (2012). Perilaku Sosial Anak Usia Dini Berambut Gimbal Di Daerah Dataran Tinggi Dieng Kabupaten Wonosobo. Journal Of Early Childhood Education Studies (IJECES) $1(1)$.

[11] Na'im, B, N. (2015). Peningkatan Keterampilan Sosial Anak Usia 4-5 Tahun Melalui Permainan Tradisional Cublak-Cublak Suweng Di TK ABA 44 Kecamatan Banyumanik Kota Semaranng. Early Chidhood Education Papers (BELIA), 46-51.

[12] Novitasari W \& Khotimah N. (2017). Dampak Penggunaan Gadget terhadap Interaksi Sosial Anak Usia 5-6 tahun. Jurnal PAUD teratai. Volume 5(3):182-6. Universitas Negeri Surabaya.

[13] Pangaribuan, T. (2017). The Correlation of Parenting Sytle with Children Social Emotional Development in Kindergarten School At Xaverius 1 Jambi. Indonesian Journal Of Early Childhood Education Studies (IJECES) 6(1).

[14] Putri, A, R, N. (2013). Efektivitas Permainan Tradisional Jawa Dalam Meningkatkan Penyesuaian Sosial Pada Anak Usia 4-5 Tahun Di Kecamatan Suruh. Early Chidhood Education Papers (BELIA), 8-16.

[15] Radliyah, dkk. (2017). Pengaruh Penggunaan Gawai terhadap Perkembangan Sosial Emosional Anak Usia Dini. Jurnal PAUD Agepedia Volume 1 No 1 Juni 2017: 1-12. Universitas Pendidikan Indonesia.

[16] Rini, R. (2017). Parents' Perception on Early Childhood Social Interaction Ability Viewed from Competitive Sports in Semarang Sport Clubs. Early Chidhood Education Papers (BELIA), 6(2), 113-119.

[17] Saputri, E. (2017). Parents in Choosing Motivation Viewed from ECD Profile Educational Institutions. Belia: Early Childhood Education Papers(BELIA), 6(1).

[18] Waygood, dkk. (2017). Children's Incidental Social Interaction During Travel International Case Studies From Canada, Japan, and Sweedan. Journal of Transport Geography 63 22-29. 